\title{
Land, Sea and Skyscape: \\ Two Case Studies of Man-made Structures in the Azores Islands
}

\section{Fernando Pimenta, Nuno Ribeiro, Anabela Joaquinito, António Félix Rodrigues, Antonieta Costa, Fabio Silva}

\begin{abstract}
The exploration of the Mediterranean seascape goes back to the foragers of the early Holocene period around the ninth millennium BCE. Two case studies in the Azores islands show possible integration of elements of landscape, seascape and skyscape in the way two different types of artificial structures were aligned. The major axes of the Maroiço structures from Pico Island may have been aligned on the summit of Pico Mountain and, reciprocally, on the setting sun at the summer solstice over the neighbouring Faial Island. The artificial caves near the sea excavated in Monte Brasil, Terceira Island, may have integrated solar calendrical marks, especially for the Equinox sunset over the distant S. Jorge Island.

\section{Introduction: Human Settlement and Colonisation History}

The Azores archipelago is located in the middle of the North Atlantic at a distance of about $1600 \mathrm{~km}$ from the European continent. The nine main islands are divided into three groups: the Western Group that includes the islands of Flores and Corvo, the Central Group with Terceira, Graciosa, São Jorge, Pico and Faial, and the Eastern group that comprises the islands of São Miguel and Santa Maria (Fig. 1).

The archipelago is located in a tectonically complex region at the junction of the North American, Eurasian and African plates (Fig.2). Portuguese navigators discovered the archipelago in 1432 and colonization began soon after, in 1439. However, the question of whether the Azores were previously inhabited has never been fully explored. References to human presence pre-dating the Portuguese settlement first appeared at the end of sixteenth century.
\end{abstract}

Fernando Pimenta, Nuno Ribeiro, Anabela Joaquinito, António Félix Rodrigues, Antonieta Costa, Fabio Silva, 'Land, Sea and Skyscape: Two Case Studies of Man-made Structures in the Azores Islands', Culture and Cosmos, Vol. 17, no. 2, Autumn/Winter 2013, pp. 107-32.

www.CultureAndCosmos.org 
108 Land, Sea and Skyscape: Two Case Studies of Man-made Structures in the Azores Islands

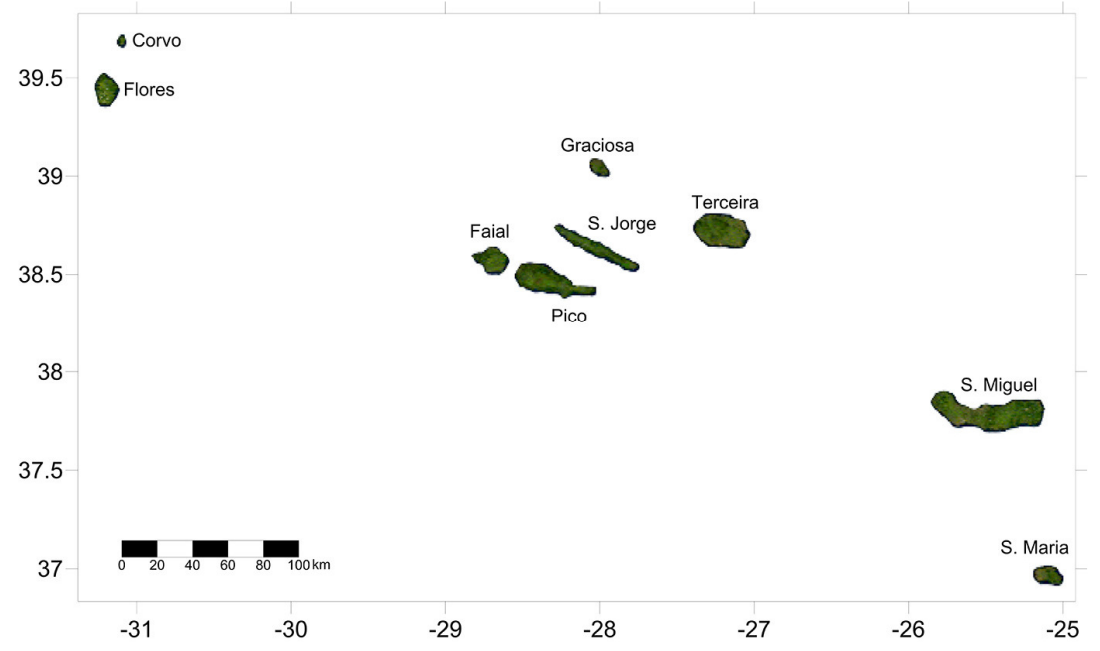

Fig. 1. Azores archipelago (axis in degrees of latitude and longitude).

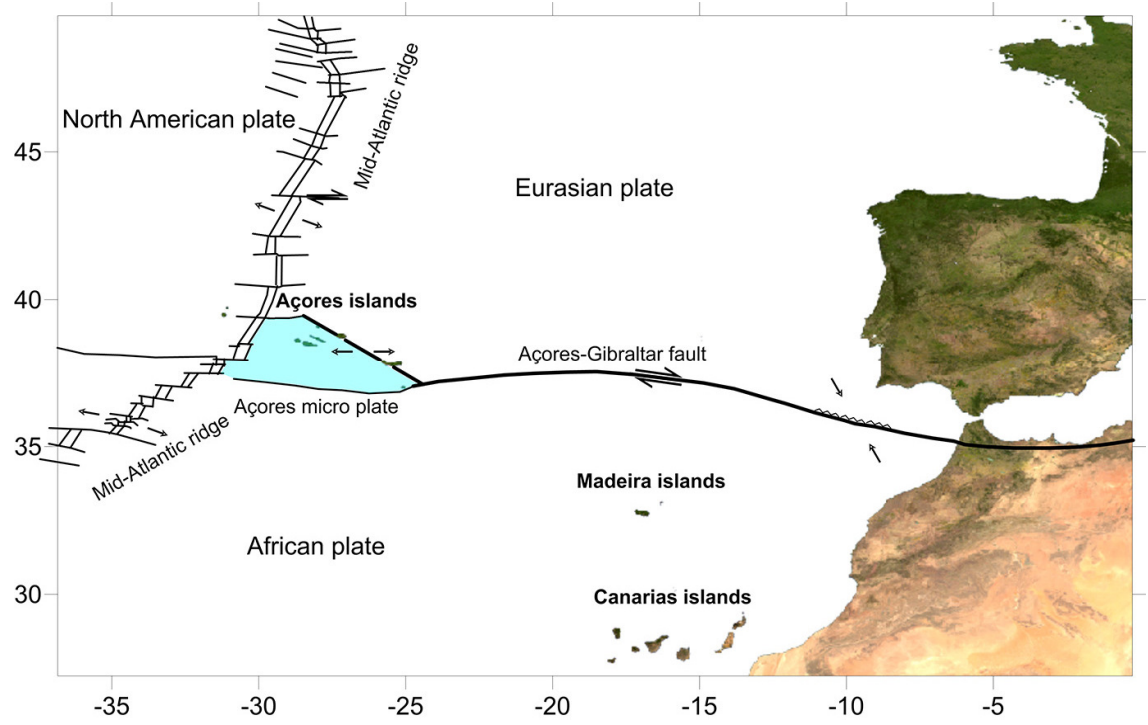

Fig. 2. Geotectonic area around the Azores archipelago; adapted from Forjaz, 1983 and Buforn et al., 1988; in Nunes, 2000 - see n 13) (axis in degrees of latitude and longitude).

A manuscript by Gaspar Frutuoso refers to a Carthaginian presence but questions whether the Azores were ever part of the mythical archipelago of

Culture and Cosmos 
Atlantis described by Plato. ${ }^{1}$ Also at the end of sixteenth century the chronicler Damião de Góis refers to an equestrian statue attributed to the Phoenicians or the Carthaginians in Corvo Island, found when the Portuguese first arrived on the island. ${ }^{2}$ References to the Azores, although of questionable veracity, had already appeared in El Libro del Conoscimiento, written in the middle of fourteenth century. A set of coins, allegedly found in 1749 in Corvo Island, were bought twelve years later by a numismatist in Madrid, who identified seven coins from Carthage and two from Cyrenaica in an article published in Sweden. ${ }^{3}$ More recently, an inscription on what could be the base of a statue is allegedly attributed to the Roman-Dacians. ${ }^{4}$ Recent work on the genetic structure of house mice indicates that the majority of $M$. m. domesticus on Santa Maria and Terceira were found to belong to a D-loop clade indicative of a lineage found in Norway, Iceland, and northern and western parts of the British Isles. ${ }^{5}$ All of the above has contributed to the debate on whether humans might have settled in the Azores before the Portuguese.

Man-made structures found on some of the islands have for years been attributed to field clearances and other agricultural and pastoral practices of the post-Portuguese colonization periods, despite the complete lack of excavation or study of any surface finds. ${ }^{6}$ However, more recently, this

\footnotetext{
${ }^{1}$ Gaspar Frutuoso, Saudades da Terra, 6 vols. (Ponta Delgada, Açores: Instituto Cultural de Ponta Delgada, 2005), Vol. 1, pp. 247-80.

${ }^{2}$ Damião de Góis, Crónica do Principe D. João, ed. Graça Almeida Rodrigues (Lisboa, 1977), Vol. 11, pp. 515-19.

${ }^{3}$ J. F. Podolyn, 'Några Anmärkingnar om de Gamles Sjöfart, i anledning af några Carthaginensiska och Cyrenaiska Mynt, fundne år 1749, på en af de Azoriska Öarne', Det Götheborgska Wetenskaps och Witterhets Samhallets Handlinger Wetenskaps Afdelningen (Först Stycket, 1778).

${ }^{4}$ Nuno Ribeiro, Anabela Joaquinito, and Sérgio Pereira, 'New Unknown Archaeological Data in Azores: The Hipogeum of the Brazil Mount, Terceira Island (Portugal), and its Parallels with the Cultures of the Mediterranean', Congress SOMA 2012, Florence, Italy. Mediterranean Archaeology. Abstracts; Herbert Sauren, 'Azores: Inscription on the Base of a Statue', 2011 at https://www.yumpu.com/en/document/view/12415814/2011-azores-dacians-netau. ${ }^{5}$ Sofia Gabriel, Maria da Luz Mathias, and Jeremy Searle, 'Genetic Structure of House Mouse (Mus musculus Linnaeus 1758) Populations in the Atlantic Archipelago of the Azores: Colonization and Dispersal', Biological Journal of the Linnean Society 108 (2013): pp. 929-40.

${ }^{6}$ Nuno Ribeiro, Anabela Joaquinito, Fernando Pimenta, and Romeo Hristov, 'Estudo Histórico Arqueológico sobre as Construções Piramidais existentes no
} 
110 Land, Sea and Skyscape: Two Case Studies of Man-made Structures

in the Azores Islands

take has been challenged by the number, type and characteristics of some of the structures. This paper presents preliminary results from two case studies, particularly focused on their landscape setting and orientation, looking at horizon visibility, axis orientation and possible alignments with landmarks, seamarks and skymarks. These suggest symbolic values that go above and beyond the purely functional roles attributed by previous interpretations.

\section{Case Study 1: The Maroiços of Pico Island}

The Portuguese settlement of Pico Island began on its southern side in 1503 and proceeded eastwards and northwards until, in 1723, because of the close trading relationship with the neighbouring island of Faial, the village of Madalena was officially founded adjacent to an important wine production area. Due to poor soils, the production of cereals in the Azores islands was always insufficient for the needs of the populations, especially so on the islands of Pico and S. Jorge. The limited wheat production was complemented by fig, yam and barley cultures and it was not until the middle of seventeenth century that this situation changed when corn was introduced. ${ }^{7}$ Corn eventually became the most important crop in the nineteenth century. Vineyards were also planted in the different islands, in volcanic soil not appropriate for wheat or woad (Isatis tinctoria) production.

In Pico Island the vineyards, belonging in their majority to owners located in nearby Faial Island, were first planted in the sixteenth century and already produced over two thousand barrels of wine per year, a quantity that rose to an average of twenty thousand by the middle of the seventeenth century. By the end of the eighteenth century it had become the most important wine production area in the Azores Islands: an average of six thousand barrels of Pico wine were exported per year to British America and Antilles. ${ }^{8}$ The vineyards were planted in the lava cracks of a

Concelho da Madalena da ilha do Pico (Açores)'. Edição Câmara Municipal da Madalena do Pico (2013), pp. 1-37.

${ }^{7}$ Rui de Sousa Martins, 'O pão no Arquipélago dos Açores: mudança e articulação das técnicas de cozedura', ARQUIPÉLAGO. História, 2a série, Vol. 2 (1997): pp. 119-70.

${ }^{8}$ Paulo Silveira Sousa, 'Para uma história da vinha e do vinho nos Açores (17501950)', Boletins, Instituto Histórico da Ilha Terceira (2004); Carlos Alberto Medeiros, Finisterra 29, no. 58 (1994): pp. 199-229; Avelino de Freitas de Meneses, 'O vinho na História dos Açores: a introdução, a cultura e a exportação', ARQUIPÉLAGO. História, $2^{a}$ série, Vol. 14-15 (2010-2011): pp. 177-86; Susana

Culture and Cosmos 
coastal strip up to $5 \mathrm{~km}$ from the sea. The orientation of the vineyards was chosen for the efficient use of sunlight and to profit from the release, during the night, of the energy absorbed by the dark basaltic stones during the day. Rainwater infiltration was maintained by a small layer of soil underneath the lava mantle. After clearing the ground, volcanic stones were used to build walls with a zigzag design to protect the vineyards from the salt-laden winds that, especially from April to June, adversely affected the grape crop. The tremendous effort to build these structures resulted in the Pico vineyard cultural landscape (Fig. 3), now listed as a World Heritage Site.

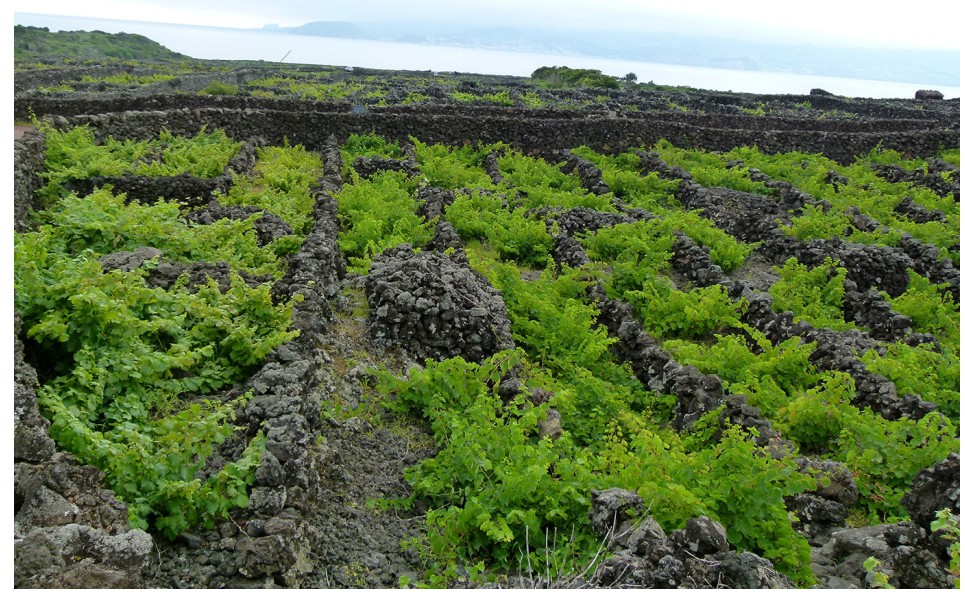

Fig. 3. Pico vineyard landscape (with Faial Island seen across the channel).

By the middle of the nineteenth century, after a devastation by Oidium and later by Phylloxera, the vineyards were sold and were replaced by a series of small farms: upper fields were cleared from stones and prepared for corn, yam and potato cultures. According to the local tradition, the monumental pyramidal structures locally called Maroiços would date from this period (Fig. 4). The construction of the Maroiços is explained, according to the popular tradition, by the need to clear the land from loose volcanic stones for agricultural use. The smaller stones that could not be

Catarina Silveira Garcia, 'Os alambiques da ilha do Pico, Açores: sistemas técnicos, património e museologia' (Masters Diss., Universidade dos Açores, Ponta Delgada, 2013). 
112 Land, Sea and Skyscape: Two Case Studies of Man-made Structures

in the Azores Islands

arranged in a wall system were piled inside and on the top of large rock piles of pyramidal or conical shapes. These large structures were organized in space together with enclosure walls to limit and protect cultivation areas. ${ }^{9}$ According to Garcia, vineyards could be planted on the Maroiços, freeing the terrain for other agricultural products. ${ }^{10}$

Structures similar to the Maroiços can be found in several other volcanic islands like Tenerife, Sicily and the Mauritius Islands. In Tenerife it is accepted, although with some controversy, that the Majanos were built in the middle of nineteenth century, to clear space for cochineal cacti plantations, due to the high market price of this carmine dye. ${ }^{11}$ According to Esteban the pyramids in the Mauritius islands may have been built there after the First World War, during a period of prosperity linked to the increase of sugar production. ${ }^{12}$

In other Azorean islands, such as Faial Island, there are structures with construction similar to the Pico Maroiços, but of much smaller size and more irregular shape. Most of the Pico Island Maroiços have staggered steps of about $1 \mathrm{~m}$ in height, a lateral ramp and some also have chambered structures inside (Fig. 4). These can divided into the following size categories:

a) Structures about $20 \mathrm{~m}$ wide by $6 \mathrm{~m}$ tall;

b) Structures about $10 \mathrm{~m}$ wide by $13 \mathrm{~m}$ tall;

c) Smaller structures between 3-5 m tall.

\footnotetext{
${ }^{9}$ Rui de Sousa Martins, 'Construções de falsa abóbada nas paisagens de pedra seca da Madalena do Pico', Madalena do Pico-Inventário do Património Imóvel dos Açores, Jorge Paulus Bruno. coord. (Angra do Heroísmo, Câmara Municipal da Madalena, 2001): pp. 27-30.

${ }^{10}$ Garcia, 'Os alambiques da ilha do Pico, Açores'.

${ }^{11}$ César Esteban, 'Arqueología soñada: la historia de las pirámides de Güímar', el escéptico (Primavera 2000); Antonio Aparicio and César Esteban, 'Sobre la possible influencia del simbolismo masónico en las orientaciones de las Morras o "Pirámides" de Chacona, en Güímar', Revista Tabona 17 (enero 2009): pp. 17587.

${ }^{12}$ César Esteban, 'Los Majanos y el don de la ubiquidad', La Opinión de Tenerife 147 (2002).
}

Culture and Cosmos 


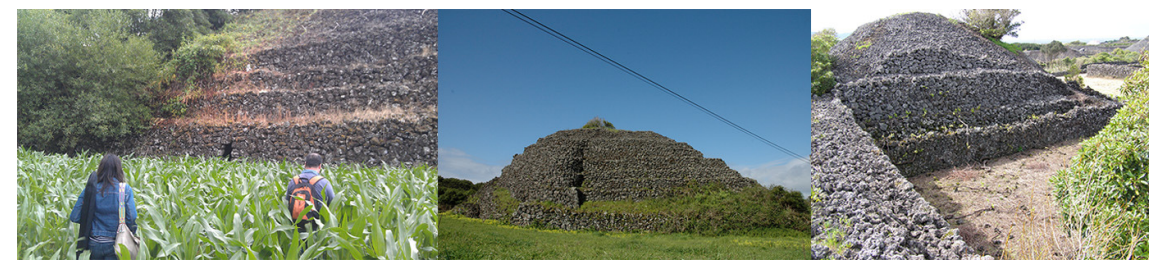

Fig. 4. Maroiço with chambered structure (left); Maroiço with staggered steps (middle); complex of Maroiços (right).

Over a hundred structures are concentrated in an area of six square kilometres, southeast of the town of Madalena (Fig. 5). For each of the 118 locations, the slope and aspect were measured / computed and the azimuth profiles of the distance to horizon, horizon height and astronomical declination (corrected for refraction) were generated.

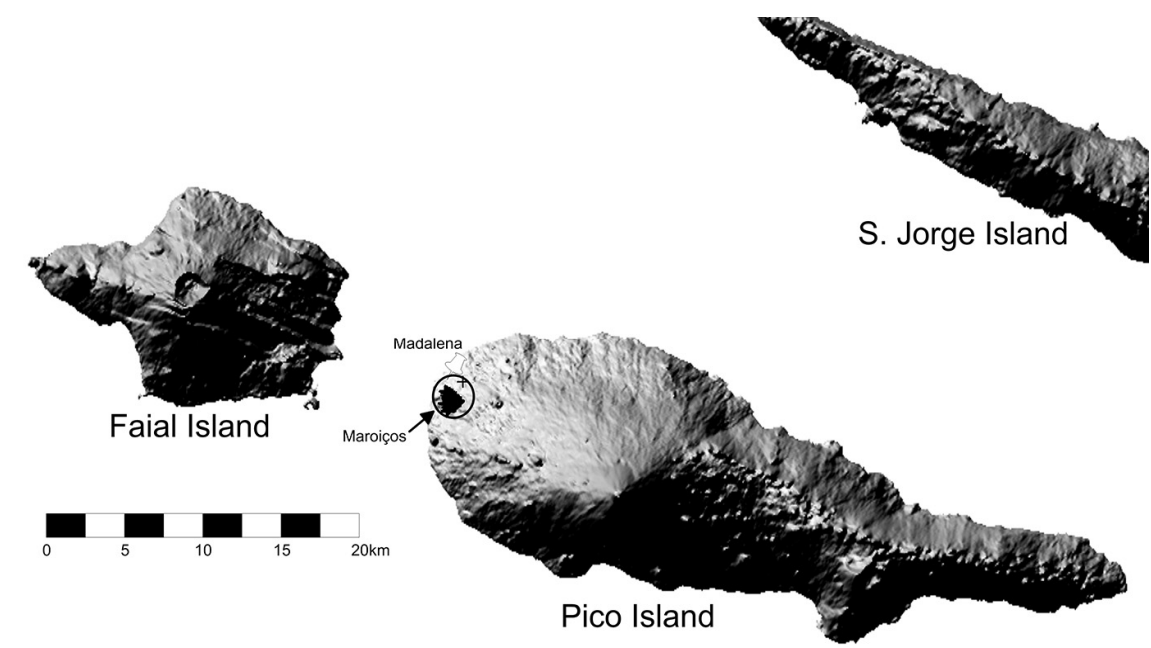

Fig. 5. Maroiços cluster to the SE of town of Madalena.

These data show that the structures are located in a terrain with a gentle west-facing slope of $+3^{\circ}$, and in locations that present a distant horizon, more than $3 \mathrm{~km}$ away, in a range between azimuths $105^{\circ}-135^{\circ}$ and $280^{\circ}-$ $330^{\circ}$ (Fig. 6). From all, the top of Pico Mountain is intervisible (i.e. have a direct line of sight with one another) to the southeast, at about $120^{\circ}$ azimuth. 
114 Land, Sea and Skyscape: Two Case Studies of Man-made Structures in the Azores Islands

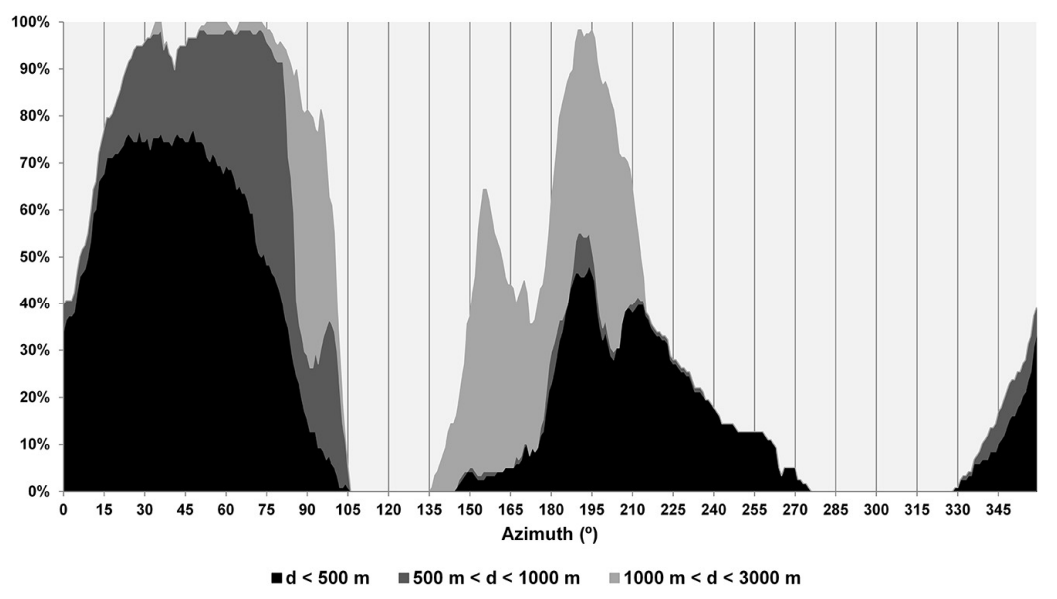

Fig. 6. Distance to horizon distribution for the 118 Maroiços in the cluster.

\section{Maroiço orientation}

The major axes of the Maroiços were defined by two ranging poles placed at both ends of several steps and at the top of the structure. The azimuth, measured along each pair of poles, was measured with a magnetic compass, and the different measurements were averaged. Magnetic declination correction was estimated using a sub-meter accuracy Differential Global Positioning Satellite system (DGPS) based on the positions recorded in the Maroiços and a distant topographic feature visible from these Maroiços, to which the magnetic compass bearing was also recorded. The measurements were later compared with an aerial photographic map, orientated to geographical north. The orientation error of the major axis, ranging from 2 to $6^{\circ}$ in azimuth, was estimated based on the ratio of lengths of major and minor axes, the degree of destruction of the structure and the instrument precision. In some cases the measurements were taken from the aerial photographic map, with a degraded error.

The striking uniformity of the orientations and their possible correlation to prevailing wind directions are illustrated in Figure 7. Prevailing winds on Pico Island are from the southwest quadrant, although from May to July it is common to have slacker winds blowing from the northeast. The strongest winds blow in winter from the southwest or the northwest. ${ }^{13}$ The

13 João Carlos Carreiro Nunes, 'A Actividade Vulcânica na Ilha do Pico do Plistocénico Superior ao Holocénico: Mecanismo Eruptivo e Hazard Vulcânico', (PhD Thesis, Universidade dos Açores, 2000); Rui Fernando da Costa Medeiros,

Culture and Cosmos 
probability of getting a similar distribution from a random circular uniform population is extremely low: p-value of 5E-34 for Chi2 test and 0 for Rao's spacing test. ${ }^{14}$

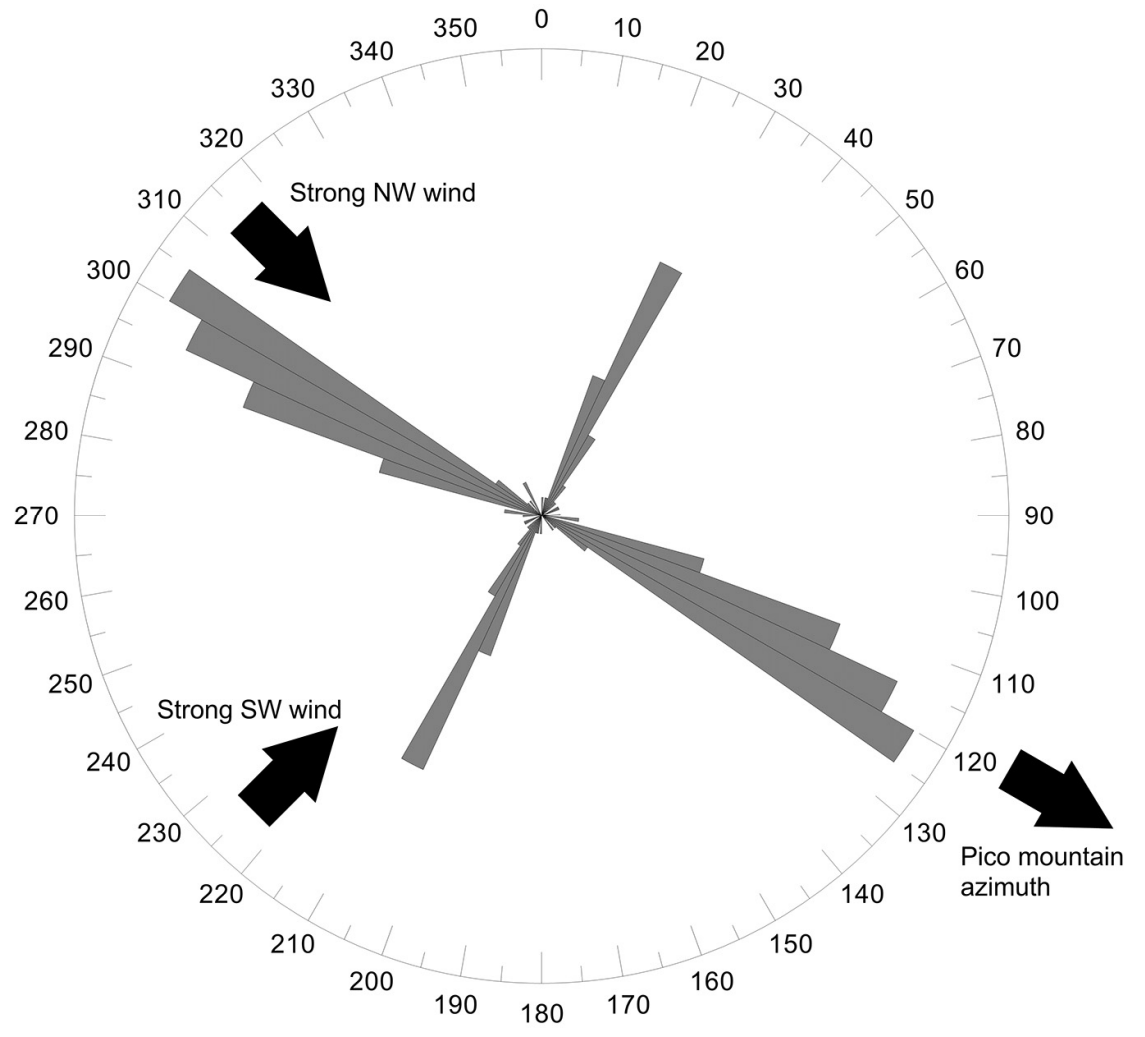

Fig. 7. Major axis orientation of the 118 Maroiços in the Madalena cluster. Strong winds occur from NW and SW. Prevailing winds are from SW.

Histograms of orientation were created via a Monte Carlo simulation using the major axis direction of each Maroiço as the mean and the estimated error for each measurement as the standard deviation. These are shown in Fig. 8 (left) for the eastern direction and Fig. 9 (left) for the western direction. In the same figures we represent, in red, the azimuth distribution

'Escoamento do ar em torno da Ilha do Pico e a operacionalidade do seu aeroporto' (Masters Diss., Universidade da Beira Interior, Covilhã, 2009).

${ }^{14}$ K. V. Mardia, and P. E. Jupp, 'Statistics of directional data', 2nd ed., (Chicester: John Wiley \& Sons, 2000). 
116 Land, Sea and Skyscape: Two Case Studies of Man-made Structures in the Azores Islands

for the Pico mountain-top as seen from each site (Fig. 8) and the azimuth distribution for Summer solstice sunset, calculated with the height of the horizon over Faial Island, as seen from each site (Fig. 9). As the figures make clear, the major axes of most Maroiços are orientated in such a way as to align with the Pico mountain top to the east, and summer solstice sunset over Faial Island to the west.

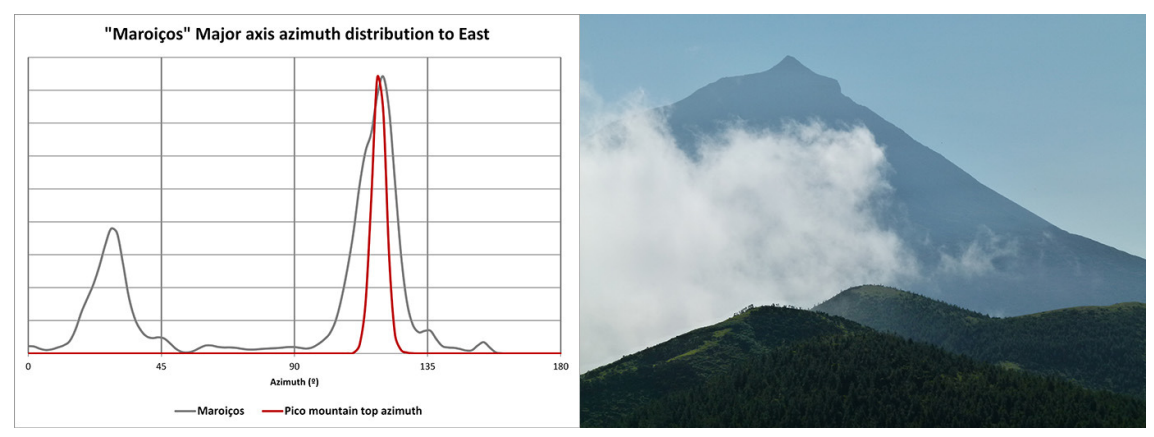

Fig. 8. Histogram for the eastern azimuths of the 118 Maroiços in the cluster (left); Pico Mountain (right).
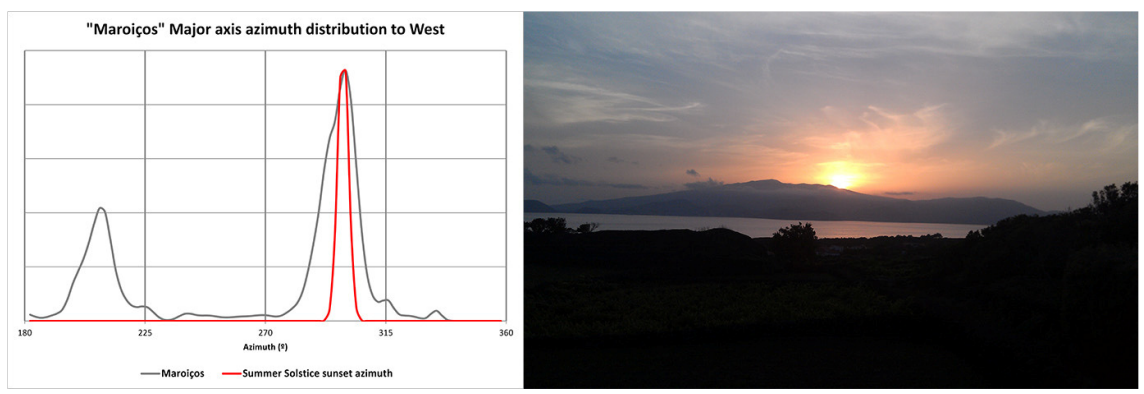

Fig. 9. Histogram for the western azimuths of the 118 Maroiços in the cluster (left); Sunset over Faial Island 11 days after summer solstice 2013 (right).

\section{Discussion}

The pattern for the major axis orientations presents strong evidence for an intentional alignment in the construction of the Maroiços. This apparent intentionality may have been driven by ecological factors, such as crop protection from prevailing winds, using a thumb rule for coarse alignment to the mountain top. However we cannot discard a symbolic motivation associated with the summer solstice. The fog, very common in summer, especially in June, blocks the view to the mountain, but this alone would

Culture and Cosmos 
not explain an alignment in the opposite direction to the summer solstice sunset. The fact that the Maroiços were built in locations that present open and reciprocal views to $120^{\circ}$ and $300^{\circ}$ of azimuth and are concentrated in a region where a dual alignment to the top of Pico mountain and the Summer solstice sunset over the island of Faial is visible, suggests an integration of a possible bidirectional alignment building convention (Figs. 10 and 11).

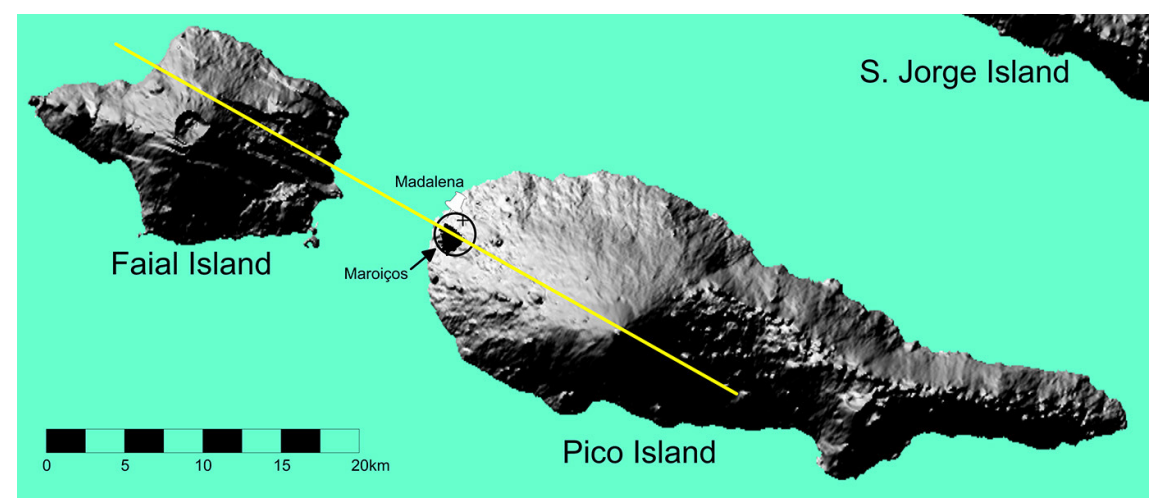

Fig. 10. Alignment between summer solstice sunset and Pico Mountain peak (yellow line). The Maroiços cluster is marked by a black circle.

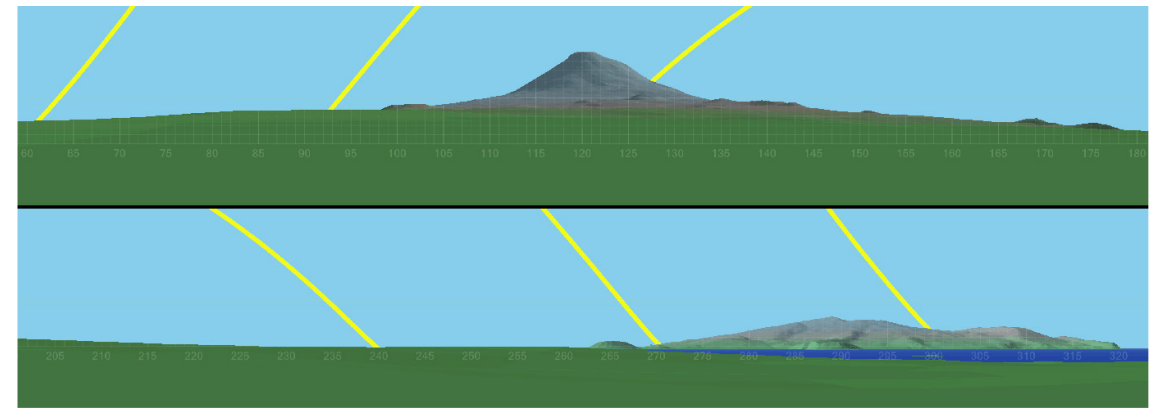

Fig. 11. Computer generated panoramas for Maroiço M7 site with sun rise and set orbits marked for the solstices and equinoxes (yellow lines): view towards Pico mountain (top); view towards Faial Island (bottom).

An archaeological survey of this cluster during the summer of 2013 provided additional data which is summarized in the appendix. ${ }^{15}$ If we

${ }^{15}$ Ribeiro, et al., 'Estudo Histórico Arqueológico sobre as Construções Piramidais existentes no Concelho da Madalena da ilha do Pico (Açores)'.

Culture and Cosmos 
118 Land, Sea and Skyscape: Two Case Studies of Man-made Structures

in the Azores Islands

accept the radiocarbon dates obtained for structure M7 then it might be difficult to explain why solar alignment symbolism may have been used by such a developed society. The sixteenth- and seventeenth-century dates, although not necessarily synchronous with the construction of the structures, do indicate that at least some of the Maroiços are older than would be expected if those structures were contemporaneous with the foundation of the village of Madalena, or built after the vineyard crisis in the middle of the nineteenth century, when large areas of land were cleared for corn plantations.

There have been associations of the Majanos in the Canaries, due to a description written by Juan de Abreu Galindo in 1632 about one Guanche practice in the Canaries, where stones were gathered in a pyramidal pile and used in rituals at particular dates in the year. ${ }^{16}$ Nevertheless other authors identified these pyramids not with the Majanos but with other structures in Roque de los Muchachos, La Palma, of circular, oval or quadrangular shapes and diameters between $1.5 \mathrm{~m}$ and $4 \mathrm{~m}$ and up to $1 \mathrm{~m}$ height, used by the Guanches for ritual practices and probably related to the piles of stones documented in sites of Gran Canaria and El Hierro, as well as the Berber kerkús. ${ }^{17}$

It is curious that in the Chacona complex, in Güimar, Tenerife, the orientation defined by the common north wall (and also by the major side of the bigger structure) is also in the direction of the summer solstice sunset. ${ }^{18}$ The excavations made in the central platform of this complex resulted in a stratigraphy compatible with an agricultural soil, with a total absence of pottery that could be dated before the nineteenth century. The absence of clear written references to the existence of these structures in the Canary Islands before the middle of nineteenth century led several researchers to associate their construction with the increase of cochineal production in the second half of nineteenth century. ${ }^{19}$ In the particular case of Chacona it has been proposed that these structures were built between

\footnotetext{
${ }^{16}$ Juan de Abreu Galindo, Historia de la conquista de las siete islas de Canaria, ed. Imprenta Lithografia y Libreria Isleña, Miguel Miranda (Santa Cruz de Tenerife, 1848): p. 175.

${ }^{17}$ Antonio Tejera Gaspar, José Juan Jiménez González, and Jonathan Allen, 'Las Manifestationes Artísticas Prehispánicas y su Huella', Historia Cultural del Arte en Canarias (2008), Vol. I: pp. 195-96.

${ }^{18}$ J. A. Belmonte, A. Aparicio, and C. Esteban, 'A Solstitial Marker in Tenerife: The 'majanos de Chacona', Archaeoastronomy 18 (JHA Vol. 24) (1993): p. 65; Esteban, 'Arqueología soñada'.

${ }^{19}$ Esteban, 'Arqueología soñada'.

Culture and Cosmos
} 
1854 and 1881, showing a solstitial orientation that could be explained by Masonic symbolism, since the then property owner was a known freemason. ${ }^{20}$ However, the large number of Maroiço structures in Pico Island does not seem to be compatible with such an explanation.

\section{Case Study 2: The Artificial Caves from Monte Brasil in Terceira Island}

Maritime traders returning from India and from the American continent used the Azores islands, and especially Terceira, as strategic harbours. Protection was assured from 1521 onwards by Portuguese fleets. With the increase of privateer activities, there was a need for permanent fleet defence units that would prevent entry into the mainland. In the middle of sixteenth century the construction of S. Brás fortress on S. Miguel Island started, followed by plans to build S. Sebastião fortress on Terceira Island. The construction of S. João Baptista fortress, also on Terceira Island, eventually started under the rule of Filipe II from Spain at the end of sixteenth century on the isthmus of Monte Brasil peninsula. ${ }^{21}$

The Caves of Monte Brasil

In Monte Brasil, five rock-cut caves are commonly attributed to having had a military or civil purpose. ${ }^{22}$ In this case study we will briefly analyse three of these caves situated in two coastal locations on the west face of Monte Brasil (Fig. 12 and Fig. 13).

\footnotetext{
${ }^{20}$ Antonio Aparicio, and César Esteban, Las pirámides de Güímar: mito y realidad (Centro de la Cultura Popular Canaria, 2006); Aparicio and Esteban, 'Sobre la possible influencia del simbolismo masónico en las orientaciones de las Morras o "Pirámides" de Chacona, en Güímar'.

${ }^{21}$ Nestor de Sousa, 'Programas de arquitectura militar quinhentista em Ponta Delgada e Angra do Heroísmo. Italianos, italianização e intervenções até ao século XVIII: a ermida de S. João Batista na fortaleza do Monte Brasil', ARQUIPÉLAGO. História, $2^{\mathrm{a}}$ série, Vol. 6 (2002): pp. 53-224

${ }^{22}$ Ribeiro et al., 'New Unknown Archaeological data in Azores'.
} 
120 Land, Sea and Skyscape: Two Case Studies of Man-made Structures in the Azores Islands
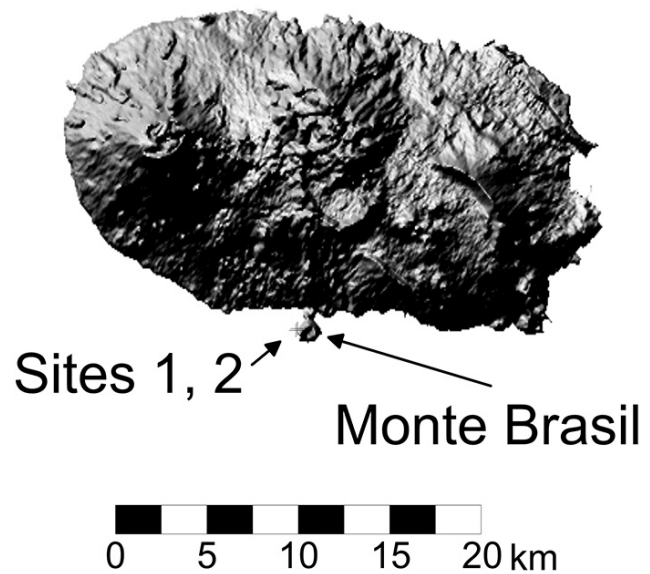

Fig. 12. Location of Sites 1 and 2 in Monte Brasil, Terceira Island.

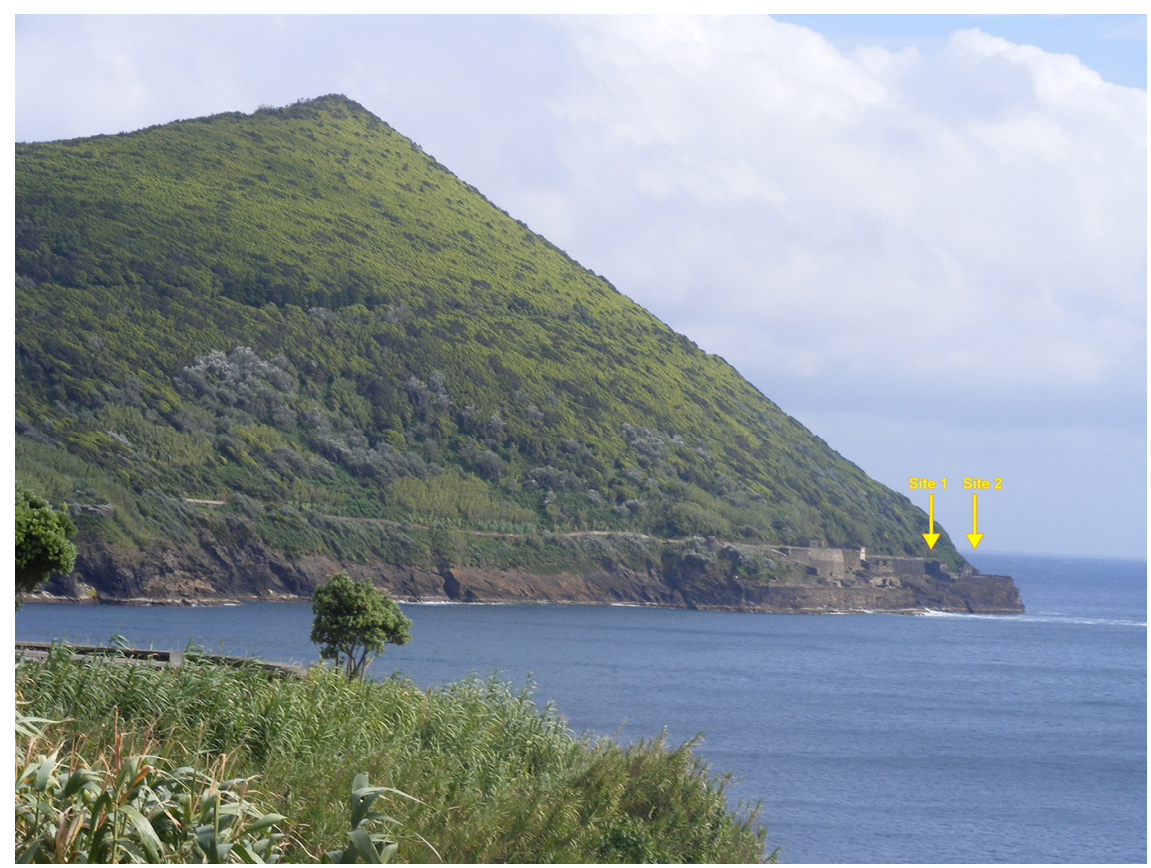

Fig. 13. Sites 1 and 2 in Monte Brasil. 
The three caves have locations that present a distant horizon between SW and NE, with the islands of Pico and S. Jorge being visible in the West far horizon (Fig. 14 and 15).

38.8

38.6

38.4

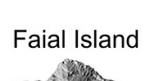

S. Jorge Island

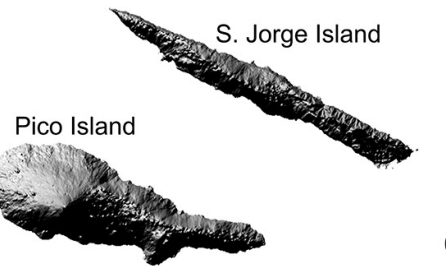

$-28$
Terceira Island
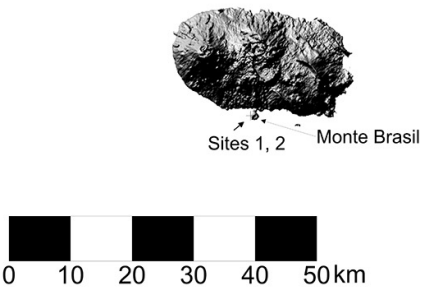

$-27.5$

Fig. 14. Islands of Pico and S. Jorge visible to the west of the sites (axis in degrees of latitude and longitude).

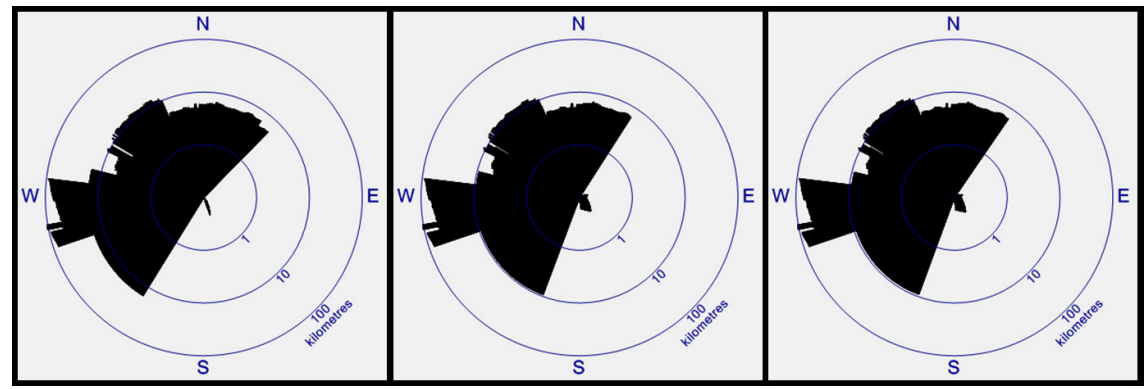

Fig. 15. Visibility (in black) from the three caves: Cave 1 (left); Cave 2 (middle); Cave 3 (right).

The cave in site 1 measures $5 \mathrm{~m} \times 4 \mathrm{~m}$ with a small water basin hewn into the back wall. There are two water-collecting channels, one on each side of the basin (Fig. 16).

An interesting light effect can be observed at equinox sunset: the entrance projects a shaft of light towards the back wall, framing the basin at the centre. Figure 17 shows a photograph and a diagram of this effect, twenty minutes before sunset (with the sun at an azimuth of $267^{\circ}$ ). At sunset, on a cloudless sky, the light projection would be centred on the back wall. This effect would only be visible for about two days around the equinoxes, if one accepts that an offset of about one degree would be visually noticeable. 
122 Land, Sea and Skyscape: Two Case Studies of Man-made Structures in the Azores Islands
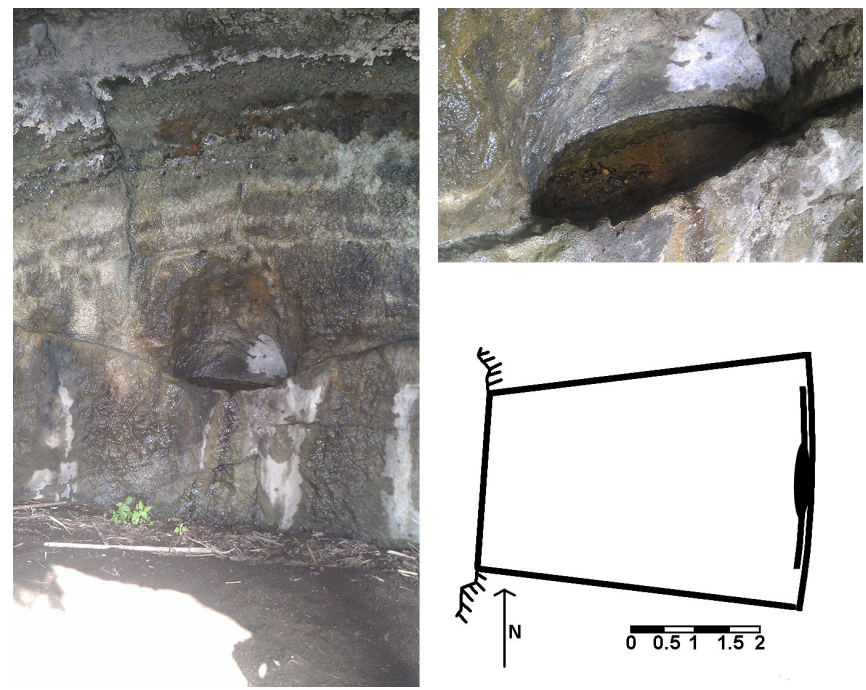

Fig. 16. Site 1 cave: cave with a small water basin (left); detail of the water basin (top right); plan of the cave (bottom right).
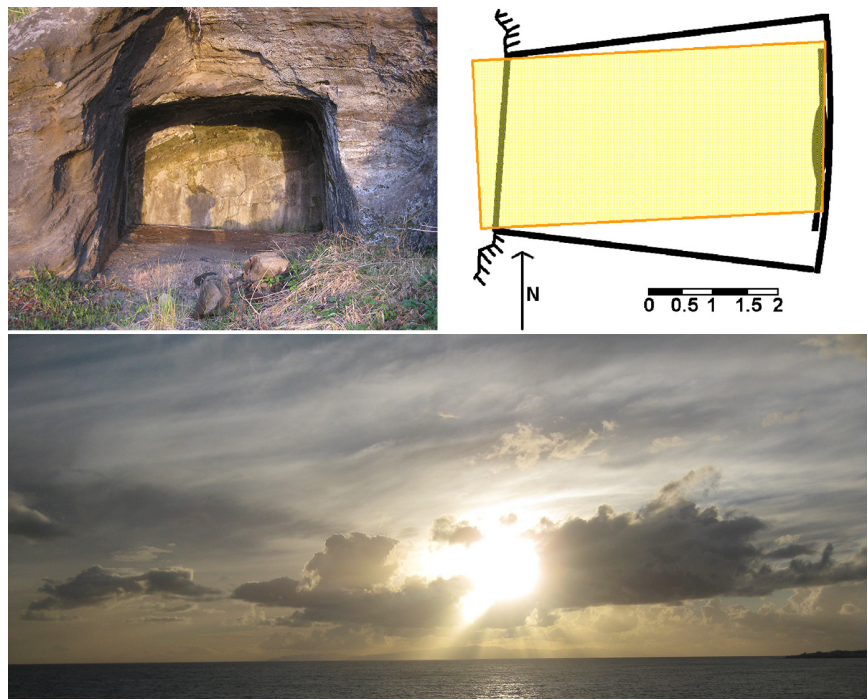

Fig. 17. Photo taken on autumn equinox 2013, twenty minutes before sunset (top left); light-shaft diagram for equinox 2013, twenty minutes before sunset (top right); Sun setting over S. Jorge Island on autumn equinox 2013 as seen from Cave 1 (bottom). Pico Island at left, S. Jorge Island in the middle and Pico at left.

Culture and Cosmos 
On the second site, located one hundred metres to the south of the first, there are three caves, two of nearly equal dimensions and a third smaller cave located in a less accessible position (Fig. 18).

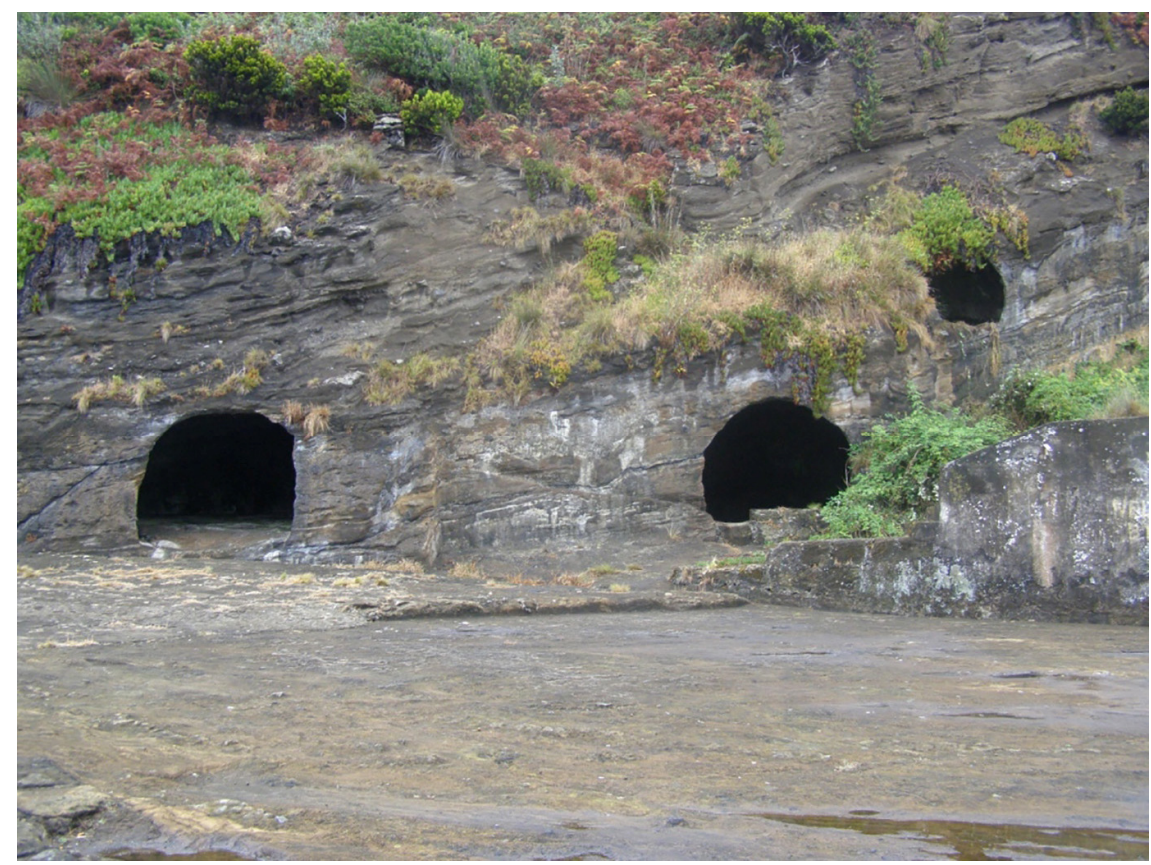

Fig. 18. The three caves from site 2 .

Cave 2, the one on the left in Fig. 18 , has a $6.7^{\circ}$ slope with a $270^{\circ}$ aspect and a channel around the walls that connects to a second, external channel. The combination of these elements would ensure that any liquid poured inside would flow out. Four basins in an asymmetrical arrangement are connected to the internal channel (Fig. 19).

Cave 3, the middle one in Fig. 18, has the same dimensions as cave 2, however its inner chamber is very different. It features several steps down to a permeable tank, with a possible seat feature at the bottom and along the walls, as well as a niche in the right corner of the back wall (Fig. 20).

Just as for site 1, some interesting illumination effects take place at sunset, especially at the equinoxes, when the light projection in the back wall touches the left-hand side wall of cave 3 (Fig. 21, left), and the left borders of the leftmost basins in cave 2 (Fig. 21, right). Three months later, 
124 Land, Sea and Skyscape: Two Case Studies of Man-made Structures in the Azores Islands

at summer solstice sunset, the light-shaft would reach the rightmost basin in cave 2 (Fig. 23, left).
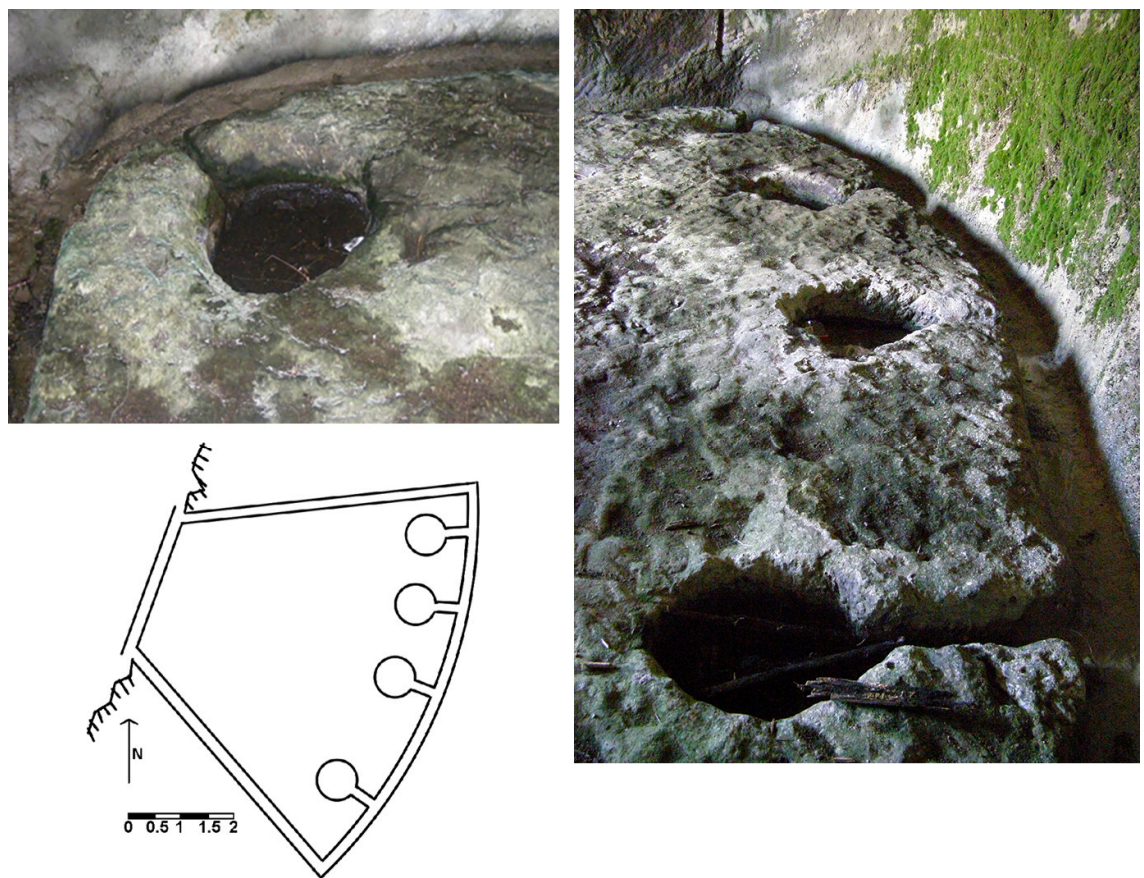

Fig. 19. Cave 2 of site 2: detail of one basin (top left); plan of the cave, with basins and channels (bottom left); the four basins at the back wall of the cave (right).
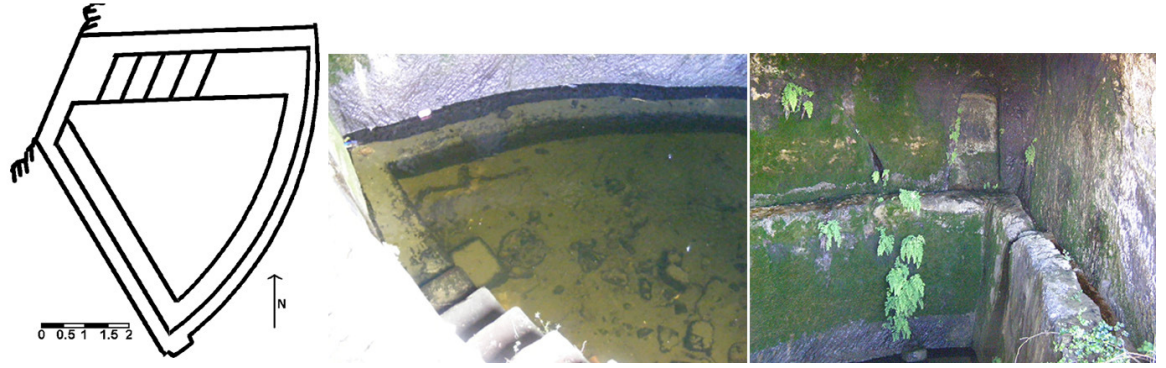

Fig. 20. Cave 3 of site 2: steps down to the tank and a possible seat (centre); plan of the cave with steps, seat feature and niche (left); the niche in the back wall (right).

Culture and Cosmos 


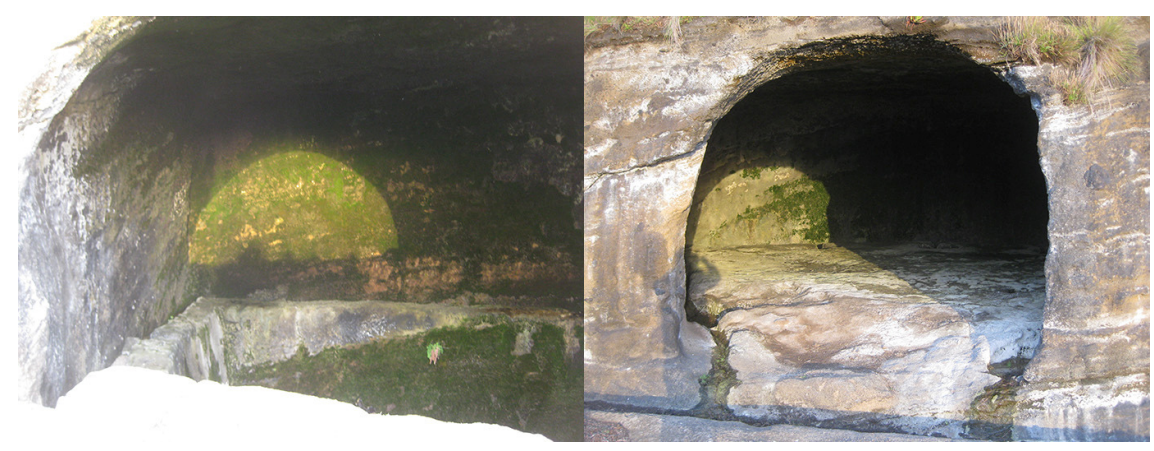

Fig. 21. Sunlight projection twenty minutes before equinoctial sunset in cave 3 (left) and cave 2 (right).

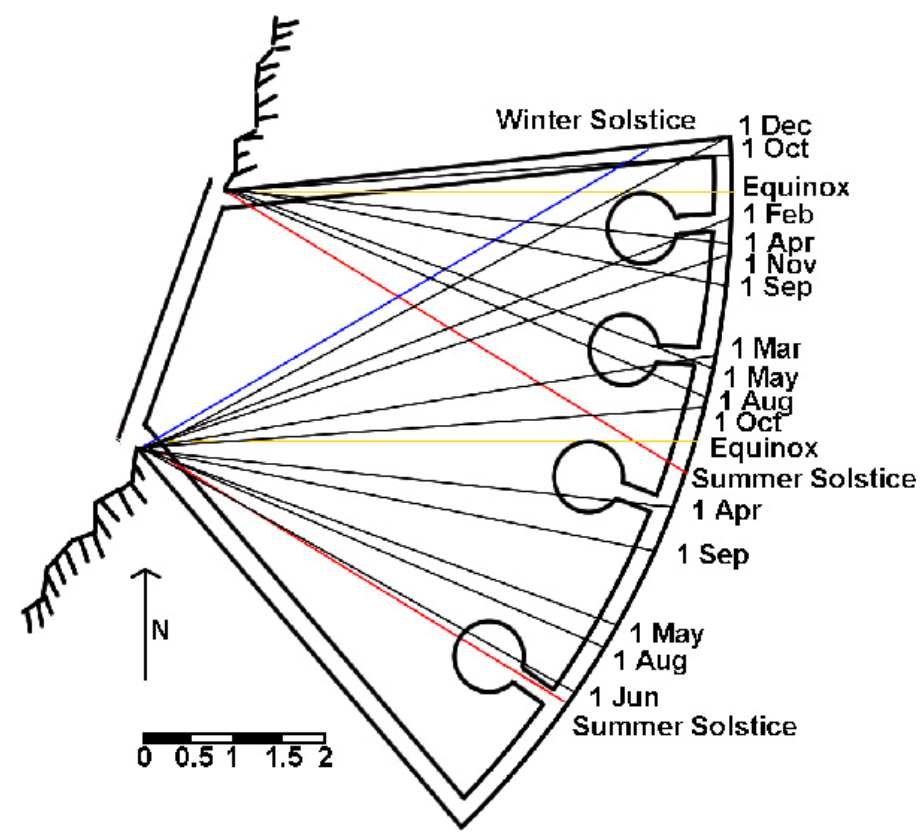

Fig. 22. Diagram of sunset projected light-shafts in cave 2, for several dates along the year. The projection moves clockwise from the Winter solstice to the Summer solstice and then anti-clockwise back to the Winter solstice. During spring and summer the projection is on the back wall. 
126 Land, Sea and Skyscape: Two Case Studies of Man-made Structures in the Azores Islands

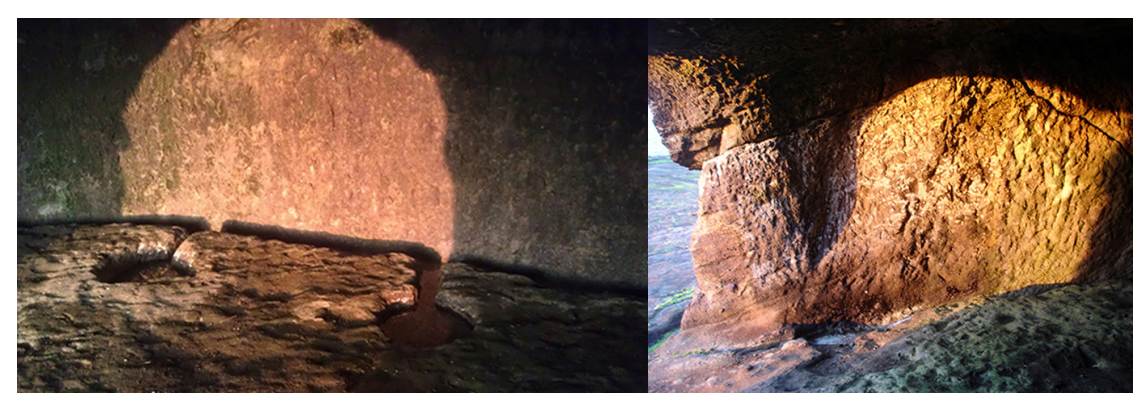

Fig. 23. Sunset illumination in cave 2, thirteen minutes before sunset, eleven days after the summer solstice in 2013 (left); Sunset illumination of the leftmost wall in cave 2 (right), minutes before the winter solstice sunset in 2013.

From all these caves sunset at the equinoxes is seen over S. Jorge Island (Fig. 17, bottom, and Fig. 24). Just as a curiosity, the niche in the right corner of the back wall from Cave 3 faces the highest point in Terceira Island, Serra de Santa Bárbara, $1021 \mathrm{~m}$ high, at $322^{\circ}$ of azimuth and $4.7^{\circ}$ of horizon height, which corresponds to $41.5^{\circ}$ of declination (Fig. 24). Such a northern declination is outside the possible positions of Sun, Moon or planets. The closest first magnitude star that had this declination was Capella around $200 \mathrm{CE}$.

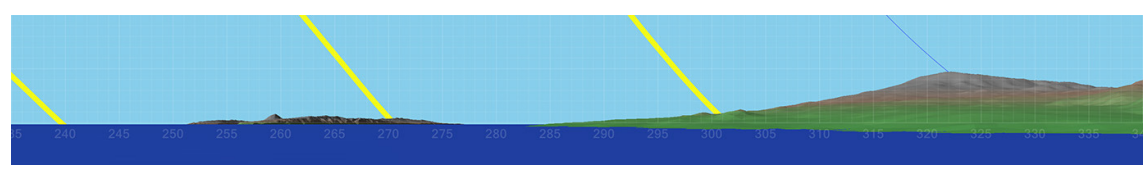

Fig. 24. Panorama generated for cave 3, with the trajectories of the Sun (in yellow) for winter solstice (left), equinox over S. Jorge Island (middle), and summer solstice (right). The peak of Santa Bárbara is seen at the left. The two islands from the central group are seen in the centre: Pico at left and S. Jorge in the middle.

\section{Discussion}

The purpose of these caves, when and who built them are not known today. Some older people, including military, informed us that from the beginning to middle of the twentieth century it was common to have people bathing in the tank from cave 3 , because the water was said to have good properties for skin treatment. However, there are no signs of thermal water as no temperature increase was measured. The water from this tank is not

Culture and Cosmos 
drinkable today: it has very high levels of silica, chloride and sodium (the last two are unambiguously related to sea spray deposits inside). It has also high levels of sulphate, probably derived from volcanic degassing.

Biogenic stalactites in cave 3 were measured and compared with similar stalactites with the same composition from a nearby water cistern with a known construction date from the seventeenth century. Assuming linear growth and the same nutrients and ambient conditions, one can compare the two stalactites to arrive at an age estimate. This suggests that the stalactites from cave 3, longer than those of the water cistern, would date to between 2000 to 400 years ago. An attempt made to date this material by radiocarbon gave a result post $0 \mathrm{BP}$, probably due to aquifer contamination by nuclear bomb tests in the 1950s, making this methodology useless.

We can speculate that these caves may have integrated some kind of Sun-related symbolism in their construction, but without any other written sources or archaeological evidence two questions remain without answer: when were those caves constructed and for what purpose?

\section{Conclusion}

This preliminary study has revealed elements embedded in the construction of the structures that required a selection process for their location and some kind of building conventions in their construction, particularly with respect to their orientation.

In the case of the Maroiços from Pico Island there is clear intentionality in their orientation. It is not possible to determine if this orientation is topographic in intent, that is whether its intent was to align with the mountain top, or archaeoastronomical, that is whether the summer solstice sunset over Faial Island was the primary intent, or indeed a combination of the two, a dual alignment. However, the geographical clustering in such a small area suggests a bidirectional, and highly symbolic, alignment, even if the main purpose of their construction might have been ecological.

In the case of the caves situated near the sea at Monte Brasil, in Terceira Island, the lack of cultural context (ethnographical, historical or archaeological) allows only speculation about the intentionality of their orientation in the direction of the three islands of Pico, S. Jorge and Faial. However, from a phenomenological point of view, the observed illumination effects at equinox, when the sun sets over S. Jorge Island, cannot be simply ignored. Had the users of these caves noticed these effects they might have incorporated them in their construction, function or symbolism. 
128 Land, Sea and Skyscape: Two Case Studies of Man-made Structures

in the Azores Islands

In conclusion, whatever was the period of construction of the Maroiços and the Monte Brasil caves, the effort in their building, their architecture and patent relation with the landscape, seascape and skyscape is enough to justify further research, excavation, as well as interest from both the local and national authorities and the public.

\section{Acknowledgments}

Landscape treatment, including distance to horizon profiles, horizon height profiles and horizon marks, was made using the panorama generated data produced by custom software developed by Andrew Smith (available at http://www.agksmith.net/horizon), to whom we are grateful, and an SRTM based modified DTM grid.

\section{Other References}

Costa, Susana Goulart and Deolinda Maria Adão. 'Discovery, Settlement, and Demographics'. In Azores: Nine Islands, One History (Açores: Nove Ilhas, Uma Historia), pp. 209-27. Berkeley, CA: UC, Berkeley, Institute of Governmental Studies Press, 2008.

Ribeiro, Nuno, Anabela Joaquinito, and Sérgio Pereira. 'Phoenicians in the Azores, Myth or Reality?'. Congress SOMA 2011, Catania, Italy. Mediterranean Archaeology. Abstracts.

\section{Appendix}

An archaeological survey during the summer of 2013 on Pico Island provided some additional data on the Maroiços cluster discussed in the main text. ${ }^{23}$ The material evidence found is summarized in this appendix.

On top of structure M112 a possible remnant of an ancient circular floor was detected. Seven basalt artefacts were retrieved from this area (Fig. A1). The corridor and chamber of the twenty metre long structure M7 was excavated. Figure A2 shows the plan and longitudinal cuts of this Maroiço. Several materials were retrieved from this excavation: metallic points and hooks; lithic artefacts probably used as fish net weights and a fragment of a stone edge; a bone artefact; shells and fragments of terrestrial fauna (Fig. A3). Finally, two coal samples, collected in two stratigraphic units inside the chamber, were also dated (Fig. A4):

- MAR7S1CUEIII, at about 40cm depth, was dated to $300+/-30 \mathrm{BP}$ : Cal 1489CE to $1604 \mathrm{CE}(69.6 \%)$ AND Cal $1610 \mathrm{CE}$ to $1654 \mathrm{CE}(25.8 \%)$;

23 Ribeiro, et al., 'Estudo Histórico Arqueológico sobre as Construções Piramidais existentes no Concelho da Madalena da ilha do Pico (Açores)'.

Culture and Cosmos 
- MAR7S1AUEIV, at about 80cm depth, was dated to $230+/-30 \mathrm{BP}$ : Cal $1530 \mathrm{CE}$ to $1538 \mathrm{CE}$ (0.9\%) AND Cal 1635CE to 1684CE (44.7\%) AND Cal $1736 \mathrm{CE}$ to $1805 \mathrm{CE}(39.2 \%)$ AND Cal $1935 \mathrm{CE}$ to post $1950(10.6 \%)$

The material record, while not explaining what may have been the original purpose of the chamber and corridor, indicate that they were, to a certain extent, used for fishing or hunting associated activities.

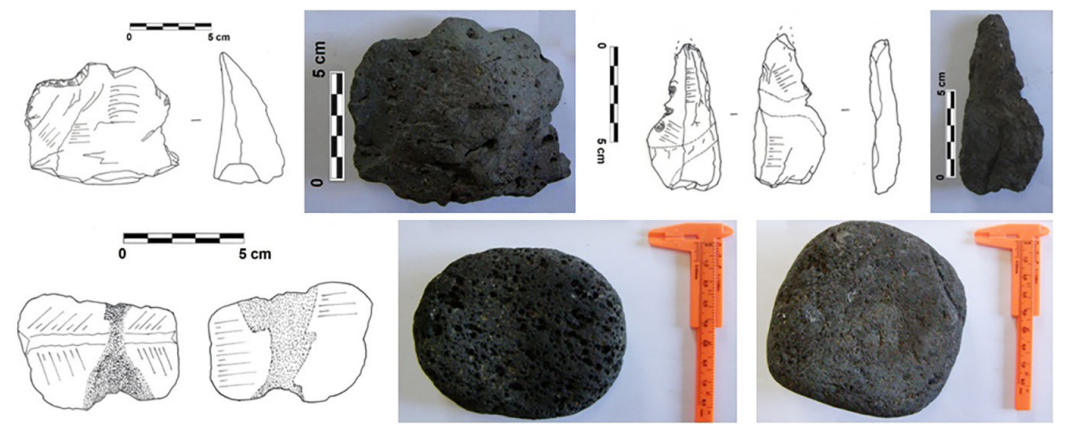

Fig. A1. Basalt artefacts found in Maroiço M112: a scraper, a flaked point with rope marks, a fishnet weight, a dormant grindstone and a polisher.

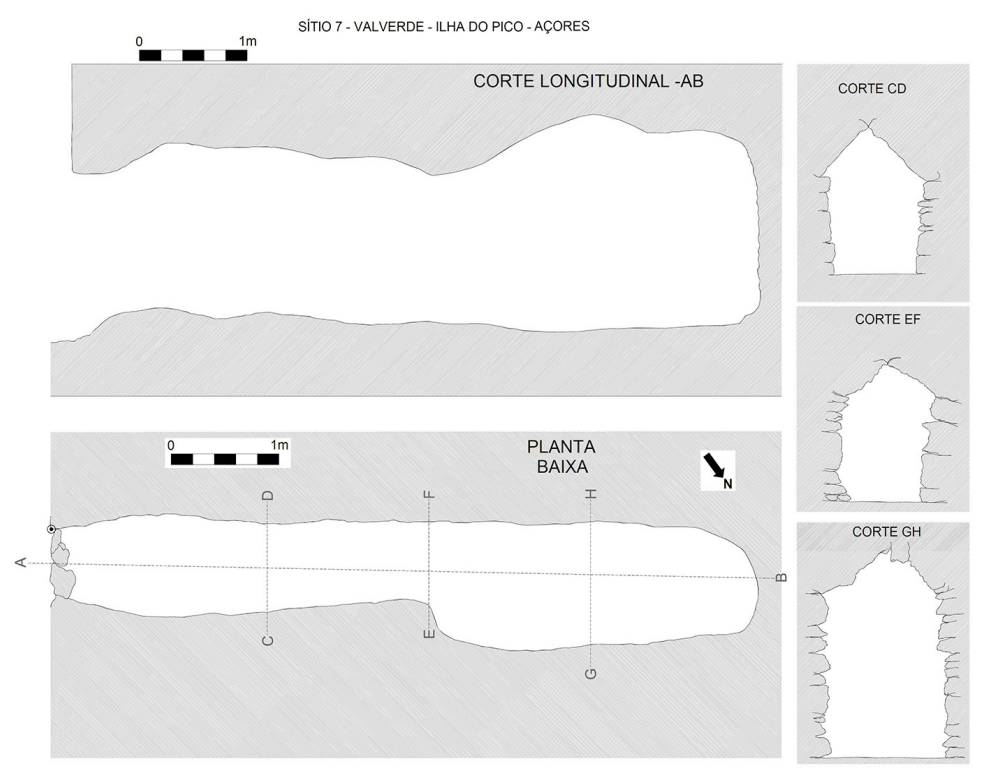

Fig. A2. Plans and longitudinal cuts of the corridor and chamber of structure M7.

Culture and Cosmos 
130 Land, Sea and Skyscape: Two Case Studies of Man-made Structures in the Azores Islands

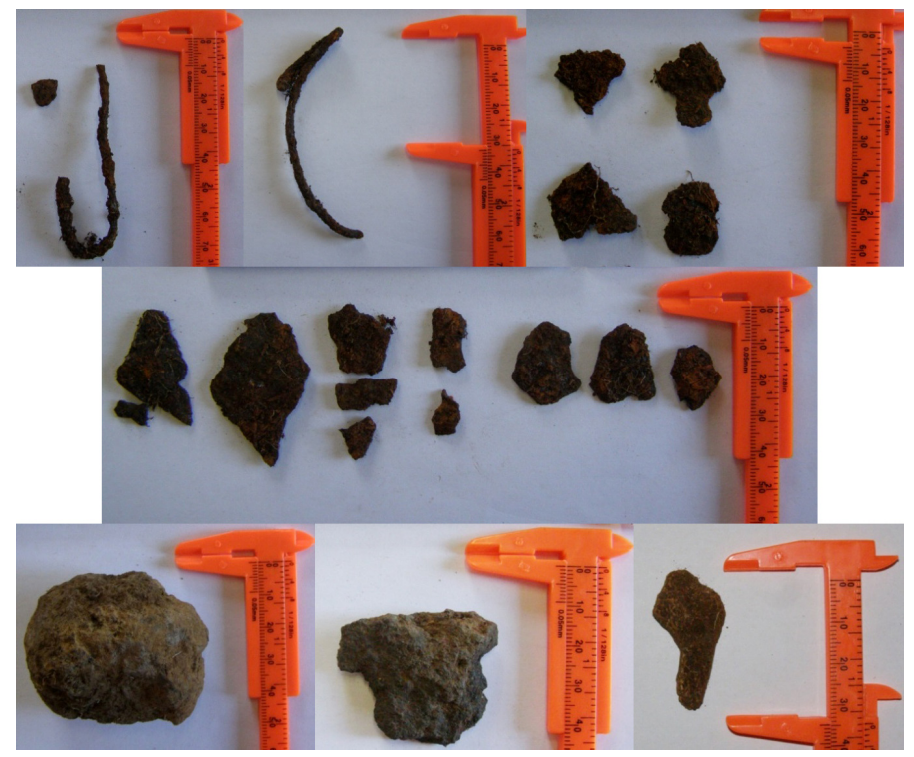

Fig. A3. Materials collected from structure M7.

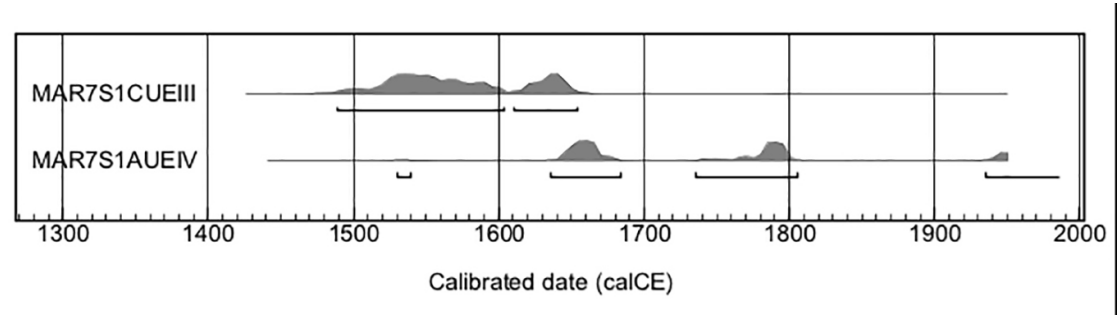

Fig. A4. Calibrated dates for the two coal samples collected in Maroiço M7. 